\title{
Factors Affecting Temple Tourism Activities- A Case Study of Taiwan Lukang Tianhou Temple
}

\author{
Ting, Chi-Hsiang ${ }^{1,2 *}$, Chang, Chin-Lien ${ }^{3}$, Dai, Quan ${ }^{1,2}$ and Cui, Xin ${ }^{1,2}$ \\ ${ }^{1}$ Faculty of Management Engineering, Huaiyin Institute of Technology, 1 E MeiCheng Rd. Huain An, Jiang Su, P.R. China \\ ${ }^{2}$ Jiangsu Smart Factory Engineering Research Centre, College of Management and Engineering, Huaiyin Institute of Technology, Huain \\ An, China \\ ${ }^{3}$ Student Affairs Office, Huaiyin Institute of Technology, 1 E MeiCheng Rd. HuainAn, JiangSu, P.R. China
}

\begin{abstract}
This study found that the factors that affect participation in temple activities are temple activity involvement, place identity, satisfaction, and willingness to revisit. They are positively correlated with each other. When the degree of involvement in temple activities is higher, the degree of recognition of local temples is higher; at the same time, the satisfaction is higher, and the willingness to revisit also increases. The degree of involvement in temple activities is positively correlated with place identity and satisfaction. And place identity is positively related to satisfaction. Satisfaction is also positively related to willingness to revisit. From this research, it is found that Taiwanese participation in temple activities is integrated with usual leisure and recreation activities.
\end{abstract}

\section{Introduction}

In the history of human development, religious activities have been virtually integrated into politics, economy, and life. Even in the age where modern science is advanced, religion is an important part of human spiritual life and leisure. Religious sightseeing is also the oldest tourist activity in history. When people participate in religious activities, they can experience the joy of sightseeing from religious activities (Chang 2015; Lee 2006, Rinschede, 1992) [1,2,3]. When scholars Nolan and Nolan (1992) [4] explored the famous Christian religious tourist attractions in Europe, they found that these religious sacred sites not only attract the attention of devout believers, but also have several characteristics that attract the secular (including non-belief). Tourists came, and summarized three categories of these religious sightseeing areas: (1) Religious pilgrimage sites (center of spiritual practice): Most tourists to the holy sites are devout pilgrims. (2) Religious tourist attraction: This attraction combines the characteristics of art, architecture, history, and sightseeing, and attracts pilgrims and general tourists. (3) Religious-related festivals and ceremonies: gather the crowd of believers and create a faith center.

From research, it is found that religion is still an important part of human spiritual life, and it has also contributed a lot to the formation of leisure tourism. People participate in religious activities to achieve the pleasure of leisure tourism. It can help human beings to relax and eliminate fatigue in the busy modern society, and then achieve the effect of leisure Vukonic (1992)[5]. Tourists' involvement in leisure refers to tourists' interest in the process of leisure activities, and their realization of the value and importance of leisure activities, and their willingness to invest in leisure activities (Hu, 1999, Yang, 2009, Wang, 2016) [6,7,8]. Therefore, as tourists are more involved in religious activities, they can also increase their willingness to invest in religious activities.

The report on the Religious and Public Life Program proposed by the Pew Research Center, an American research organization, pointed out in the survey report that it will conduct survey data statistics on the United States and more than 20 other countries. The religious diversity index scores a full score of 10 . Among the countries with the highest index, Taiwan is one of the top regions. Research points out that religion can make people healthier, happier, and more involved in community activities [9].

According to data released by the Bureau of Democracy, Human Rights and Labor Affairs of the US State Department, as many as $80 \%$ of the population in Taiwan believe in some form of traditional Taiwanese folk beliefs or Taiwanese religions mixed with Buddhist beliefs. Therefore, in a broad sense, the Buddhist population confused with Taoism in Taiwan can be said to be as large as $80 \%$. Taiwanese Buddhism refers to the Buddhist culture believed by residents in Taiwan, with a population of approximately 5.486 million believers. The number of believers may overlap with Taoism, Confucianism, or other Taiwanese folk beliefs. Taiwan's Ministry of Internal Affairs survey statistics website (2015) pointed out that the total number of temples and churches is 15,422 , with the largest number of temples, followed by churches. "five steps a small temple and ten steps a large temple temple" special phenomenon.

* Corresponding author: djs55211@qq.com 
There are more than 870 Mazu temples all over Taiwan, which is more than other temples. Therefore, by exploring the religious tourist attractions of Mazu in Taiwan, this study takes the successful factors of the religious tourism cultural development of Lukang Tianhou Temple with a history of more than 300 years as the research object, as a policy reference for those who intend to promote religious tourism cultural development activities. Research purposes: (1) Explore the differences in the involvement of tourists with different attributes in temple activities. (2) Explore the ways, motives and purposes of tourists with different attributes involved in temple activities. (3) Explore the factors affecting participation in temple activities.

\section{Literature review}

\subsection{Temple tourism involvement}

The research on involvement theory can be traced back to 1946. The "self-involvement" proposed by the American scholars Sherif and Cantril was used to predict a person's attitude toward others' persuasion (or the opposite opinion) due to his status or role. After Krugman (1965) [10] studied "low involvement consumer behavior", he transferred the concept of "involvement" from social psychology to the study of consumer behavior, and "involvement" gradually It has become an important variable in consumer behavior research and is widely used in the measurement of consumer attitudes and behavior.

In terms of religious tourism involvement, with the changes of the times, most pilgrims' motivations are not pure religious piety as in the past, which contain many different levels of motivational needs. In addition to religious pilgrims, religious holy sites also include nonreligious tourists who are interested in religious holy sites (Vukonic, 1992; Rinschede, 1992) [11,12]. The Vatican Catholic Court has clearly defined religious tourism: "Within its jurisdiction, all religious tourist attractions related to beliefs, regardless of their scale, provide services related to religious or non-religious visitors. The category of religious tourism ( $\mathrm{Yu}$ Xingjuan, $\mathrm{Yu}$ 2000) [13], for pilgrims, religious tourism is the most common way to visit sacred places for religious reasons. At the same time, it can also show the manifestation of its outward behavior and inner spirit (Barber, 1993) [14].

Yan (2000) [15] summed up two views on religious tourism in a narrow sense and a broad sense: the narrow view advocates that religious tourism refers to tourism activities undertaken by religious believers for religious purposes; such as pilgrimage, seeking Dharma, spreading the law, wandering and so on. The broad view is that tourism activities around religious tourism resources can be regarded as religious tourism. It not only includes tourism activities undertaken by religious believers for religious purposes, but also includes nonreligious believers out of interest, such as experiencing religion and its cultural connotation, or engaging in academic investigations, viewing religious art, artifacts, and holy sites. Based on the definitions of the above scholars, "religious involvement" refers to the stimulus to personal values, needs, and the outside world when a person's inner and outer environments are different, and affect the judgment or cognition produced by the individual when stimulated. The difference or importance is different. The higher the degree of participation, the higher the degree of involvement. The psychological feelings of self-loving religious activities will be different from others.

\subsubsection{The measurement of temple tourism involvement}

Laurent \& Kapferer (1985)[16] proposed that activities involved include interest, pleasure, perceived risk, and self-expression. They believe that the structure of recreation is composed of lasting involvement, consisting of four components: importance, pleasure, self-expression, and life form center. McIntyre \& Pigram (1992) [17] is an extension of Laurent and Kapferer's theory. In the research, it is proposed that activity involvement should include three parts: attraction, selfexpression, and life form center. Kyle \& Chick's (2002)[18] research on activity involvement also focuses on three dimensions: the centrality of life, attractiveness and self-expression. The meanings represented by these three dimensions are respectively The following are as follows: (1) Attraction refers to the intensity of the experience, the degree of pleasure and the concentration of interest recognized by the participants for the activity, and the pleasant feeling that an individual gets after connecting a certain mood feeling to a certain situation. (2) Self-expression is a phenomenon of individual selfrepresentation, through which the individual recognizes the feeling of individual self-identity through the behavior in the activity. (3) Centrality of life style is participating in activities and forming influence in social circles plays an important and influential role in the lives of participants.

\subsection{Place attachment}

\subsubsection{The factors of place attachment}

In terms of academic discussion, the so-called space and place are often mixed, suggesting that it is not only a pure physical space, but also has history, experience, emotion, meaning, symbols, etc. It is a different type of culture to present the trajectory. The spatial perception is more abstract, without a fixed shape, it is difficult to describe in detail (Tuan, 1977) [19]. Place attachment is a result of being attached and the definition of feeling place attachment is the positive emotional connection between human beings and a specific place (Shumaker and Taylor, 1983) [20]. Kaltenborn (1997) proposed that "place" includes three meanings in social science: Location refers to the area where people are when they engage in social and economic activities. Locale refers to the place where daily life and society interact. Sense of place refers to the emotional belonging of an individual 
to place identity and dependence, and the semantic expression similar to the sense of place is place identity.

Place attachment can also be regarded as a kind of behavior, because time and place attachment are related. When an individual has a strong identification with the place and integrates himself into the environment, this behavior will be manifested. People's participation in things and activities in the place, as well as in-depth understanding and involvement, after understanding and experiencing the environment, the positive meaning of personal memories of the place can promote positive emotional connection between people and the place (Ainsworth \& Bell, 1970; Tuan, 1977; Scannell \& Gifford, 2010; Bricker \& Keratetter, 2010). $[21,19,22,23]$. Place is attached to a place after an individual has experienced it, and the sense of dependence that can satisfy self-trust generated in the environment is called place dependence. As well as the sense of identity, belonging and connection with other emotional levels of a place at the emotional level, it is the place identity (Feldman, 1998; Shannon \& Edward, 1995)[24,25]. The study found that most scholars still focus on the two dimensions of "place dependence" and "place identity" as the main research axis (Bricker \& Kerstetter, 2010; Moore \& Grafe, 1994)[23,26]. Therefore, the above-mentioned dimensions are adopted in this study to measure the dimensions.

\subsubsection{Place dependence}

Place dependence is a kind of attachment to a special place to meet the purpose and needs of local residents. This dimension reflects the importance of a certain environment for user activities and its strong dependence on the environment and its resources. The functional dependence of "place dependence" on the degree of dependence on special activities and the special environment reflects that a certain resource can provide a necessary and convenient ability for certain activities, and users will rely on the functions provided by this resource, and may use this to engage in related activities to achieve the behavioral goals of the individual in the local area and highlight the value of the individual (Moore \& Grafe, 1994; Bricker \& Keratetter, 2010)[26,23].

\subsubsection{Place identity}

Place identity refers to the emotional and symbolic meaning given by the individual to the place. It is based on the individual's emotional maintenance of the place and the individual has a strong sense of belonging to the place. It is the individual's physical environment, beliefs, preferences, feelings, values, and goals for the place., Behavioral orientation, and technology-related identity. Moreover, place identity usually comes from a sense of belonging to the field, with strong desire and emotional attachment, and its psychological level of feeling is the emotional and symbolic meaning produced by the process of time experience and experience (Proshansky,
Fabian, \& Kaminoff, 1983; Bricker \& Kerstetter, 2010) [27,23].

\subsection{Satisfaction}

In the field of leisure research, Baker \& Crompoton (2000) [28] believes that overall satisfaction is a measurement of the overall feelings of tourists after experience, and sub-satisfaction refers to the satisfaction of recreational activity attributes, including: landscape resources, operation management, facility sanitation And service quality. In addition, scholars Beard and Ragheb (1980) [29] defined "leisure satisfaction": leisure satisfaction is a positive view or feeling formed or acquired by an individual in a certain leisure activity. The degree to which the individual feels satisfied or satisfied with his current leisure experience and situation. This positive sense of satisfaction comes from the individual's own perception or satisfaction of undetected needs. In this research, the "Leisure Satisfaction Scale" was developed to measure the degree to which individuals perceive personal needs through participating in leisure activities. The scale is divided into six dimensions: psychological, educational, social, relaxing, physical, and aesthetic.

\subsection{Discussion on the relevance of temple tourism involvement, place attachment, satisfaction, and willingness to revisit}

The relationship between tourism involvement and place dependence has been confirmed in past studies, and there is a positive relationship between the two. Many empirical studies have also found that activity involvement is one of the antecedent variables of local dependence, that is, the degree of activity involvement will affect the degree of place dependence, and individuals will become dependent on activity-related facilities or venues in a relatively short period of time After feeling, they will also have a sense of identity with the leisure environment related to the activity (McFarlane, Boxall, \& Watson, 1998; Moore \& Graefe, 1994; Schreyer, Lime \& Williams, 1984; Peng, 2004) [30,31, 32].

The frequency of participation in activities and the degree of involvement will affect the strong sense of place attachment. As resource users participate in different leisure activities, their sense of attachment to the place will be different (Tung, 2016)[33]. In the research, it is found that religious views are related to each other in terms of involvement, satisfaction, and loyalty (Chu, 2014) ([34]). In Liu (2008)[35] survey results found that there is a relationship between temple tourism involvement, place dependence and satisfaction. There is a significant positive correlation between temple tourism involvement and place attachment. Place attachment and satisfaction are also significantly positively correlated. From the above literature and research results, it can be inferred that factors such as temple activity involvement, place attachment, satisfaction, and willingness to revisit are related to each 
other. Therefore, this study assumes that the relationship between the tourist factors that influence tourists' participation in the Tianhou Temple in Lukang, Changhua County is: H1 Temple tourism involvement has a positive impact on place attachment. H2 The involvement of temple tourism involvement has a positive impact on satisfaction. H3 Place attachment has a positive effect on satisfaction. H4 Satisfaction has a positive effect on willingness to revisit.

\section{Research methods}

\subsection{Sampling design}

Convenience sampling will be used for sampling in this study. The sampling objects are tourists who visit and relax at Tianhou Temple in Lukang. The questionnaires for this study were distributed in June 2020. The pre-test questionnaires were collected and 50 copies were collected. The revised official questionnaires were distributed from July 2020 to November 2020, and 260 copies were collected. The recycling rate was $86 \%$. In this study, Lukang Tianhou Temple was used as the research base, and questionnaires were distributed through the management department of Lukang Tianhou Temple. The question items are measured using the Likert five-point scale, from "strongly agree", "agree", "normal", "disagree", "strongly disagree", and give scores of $5,4,3,2,1$, respectively.

\subsection{Questionnaire design}

This study uses the "closed questionnaire" as a research tool and is drawn up with reference to relevant domestic and foreign documents. The content of the questionnaire is divided into 5 parts. The first part is to measure the degree of tourist involvement in temple activities. The second part is to measure the degree of tourists' dependence on Lukang Tianhou Temple. The third part is to measure tourists' satisfaction with Lukang Tianhou Temple. The fourth part of the investigation is the willingness to revisit. The fifth part is the basic information of tourists. The contents of the questionnaire are as follows:

(1) Involvement activities

The question in this part is to explore the degree of involvement of the interviewee in temple activities. This research is based on the use of McIntyre and Pigram (1992) [17] to divide the aspects of recreational involvement into three parts. They are attraction, centrality to lifestyle, and self expression. In this study, Kyle, Bricker, Graefe \& Wickham (2004) [37] and Tung (2011) [33] research concepts and questionnaire questions were used as references for the revision of questions.

(2) Place attachment

The second part is the scale of the degree of Place attachment of local residents to the Tianhou Temple in Lukang. This study uses the two dimensions of "place dependence" and "place identity" adopted and repeatedly verified by most scholars to measure place dependence.
Based on the research of Kyle, Graefe, Manning \& Bacon (2003) [36]), the main development basis of the questions in this part. The revised survey questionnaires of research papers by Peng (2004) [32] and Ting \& Chang (2016)[38] are used as reference.

(3) Measurement aspects and items of temple sightseeing satisfaction

Satisfaction of temple sightseeing adopts the leisure satisfaction mentioned in the papers of Baker \& Crompoton (2000) [28], Lai Yixuan (2014) ([38]), Zhu Yuhui (2014) [34] and is divided into 3 parts : (1) psychological needs (2) environmental needs (3) aspects of cultural preservation of ancient achievements, etc., as the questionnaire items of this research survey.

(4) willingness to revisit

Refer to Shen \& Hsieh (2003) [40] and Lai, (2014)[39] questionnaire questions. And list item 1. Interviewees are also willing to come back to Lukang Tianhou Temple again. Item 2 . Whether the respondent is willing to recommend others to Lukang Tianhou Temple, as a measure.

(5) Tourists' attributes and recreational motives and goals

This part is to explore the attributes of different tourists, including their socio-economic background, recreational motivation and purpose. Investigate the difference in passengers' social and economic background and their motivation and purpose for participating in recreation, including gender, age, marital status, education level, personal monthly income, activity purpose, activity frequency, transportation, and companions.

\section{Data analysis}

This chapter analyzes and discusses the results of research investigations based on the data obtained from research investigations. First, go through the pre-test on the questionnaire items in Section 1 to understand the reliability of the questionnaire tools. Section 2 conducts narrative statistics on the socio-economic background and participation characteristics of tourists in Lukang Tianhou Temple to understand the distribution characteristics. Section 3 uses the least square method to find out the correlation in disguised form.

\subsection{Pre-test questionnaire design}

The variables of this study are pre-tested before the questionnaire is officially tested, and the pre-test questionnaire is subjected to factor analysis and reliability analysis. Refer to the responses of the testees; in addition to deleting and modifying some of the inapplicable questions, we also add and delete measurement questions for the aspects of poor analysis results in order to improve the reliability and validity of the questionnaire content and improve the quality of the questionnaire. Scholars believe that Cronbach's $\alpha$ is acceptable as long as it is 0.5 or above. If it is between 0.6 and 0.9 , it is a high confidence value. The standardized reliability coefficients of each part of the 
scale of this study, the reliability of involvement in temple tourism involvement (Cronbach's $\alpha$ ) 0.940, the reliability of local attachment (Cronbach's $\alpha$ ) 0.945 , the reliability of satisfaction (Cronbach's $\alpha$ ) 0.927 , the willingness to revisit (Cronbach's $\alpha$ ) 0.942, between 0.817 and 0.917 , each part of the scale has a fairly good reliability value, as shown in Table 1.

Table 1. Reliability analysis of various factors.

\begin{tabular}{|c|c|}
\hline factor & Cronbach's $\alpha$ \\
\hline $\begin{array}{c}\text { temple tourism } \\
\text { involvement }\end{array}$ & 0.940 \\
\hline place attachment & 0.945 \\
\hline satisfaction & 0.927 \\
\hline Willingness to revisit & 0.942 \\
\hline
\end{tabular}

\subsection{Analysis of sampling data}

\subsubsection{Social and Economic Background of Tourists}

This study takes tourists from Lukang Tianhou Temple as the sample object, and there are 8 items of socioeconomic background information, including gender, age, marital status, education level, occupation, personal monthly income, residential area, religious beliefs, etc. This is the distribution of the respondents in the analysis of the socio-economic background in this study. The related narrative statistical analysis results are as follows:

(1) The gender distribution ratio of the respondents: 103 men accounted for $39.6 \%$, and 157 women accounted for $60.4 \%$. (2) The age distribution of the respondents: $13.5 \%$ are under 20 years old with 35 people accounting for $13.5 \%, 21-30$ years old with 106 people accounting for $40.8 \%, 31-40$ years old with 55 people accounting for $21.2 \%, 41-50$ years old with 47 people Accounted for $18.1 \%, 10$ persons aged 51 to 60 accounted for $3.5 \%$, and 7 persons aged over 60 accounted for $2.9 \%$. (3) The distribution of the respondents' marital status: 177 people who are unmarried account for $68.1 \%, 6$ people who are married without children account for $2.3 \%$, and 77 people who are married with children account for $29.6 \%$. (4) Respondents' educational level distribution ratio: 1.2\% have 3 persons with a junior high school degree or below, $1.2 \%$ have 3 persons with a national high school degree, $12.3 \%$ have 32 persons with a high school (high vocational) degree, and 205 persons have a college/college degree. $78.8 \%$ of the people, and 17 people with a graduate school (including) or above accounted for $6.5 \%$. (5) Respondents' occupational distribution ratio: 54 in industry accounted for $20.8 \%$, business accounted for 27 people accounted for $10.4 \%$, civil servants accounted for 27 people accounted for $10.4 \%$, service industry accounted for 89 people accounted for $34.2 \%$, free industry accounted for 14 people accounted for $5.4 \%, 7$ housewives accounted for
$2.7 \%$, and 42 students accounted for $16.2 \%$. (6) Respondents' average monthly income (NTD): $8.1 \%$ of respondents with 21 people under 10, 000 dollar, 74 people with 1,0001-20000 dollar 28.5\%, 72 people with 2,0001-30000 dollar 27.7\%, 47 people with 30001 $\sim 40,000$ dollar accounted for $18.1 \%$ of, 18 people of $40001 \sim 50,000$ dollar accounted for $6.9 \%, 19$ people of 50001 dollar or more accounted for $7.3 \%$, and 9 people without irregular income accounted for 3.5\%. (7) Respondents' living area distribution ratio: Northern Taiwan has 6 people accounting for $2.3 \%$, Central Taiwan has 223 people accounting for $85.8 \%$, Southern Taiwan has 27 people accounting for $10.4 \%$, and 4 people in the eastern and western regions of Taiwan account for $1.5 \%$. (8) Religious belief distribution ratio of the respondents: 87 people in Buddhism accounted for $33.5 \%, 108$ people in Taoism accounted for 41.5\%, Christianity accounted for 6 people accounted for $2.3 \%$, Islam accounted for 1 person accounted for $0.4 \%$, and no religious belief accounted for 58 people accounted for $22.3 \%$

\subsubsection{The purpose, motivation and characteristics of recreation}

This study takes tourists from Lukang Tianhou Temple as the sample object. There are 6 types of recreational attributes of tourists, namely recreational purpose, recreational frequency, transportation, companions, information source, average consumption amount, etc. This is the distribution of respondents in the analysis of recreational attributes in this study. The relevant narrative statistical analysis results are as follows:

(1) The survey sample found that the main purpose of the interviewees going to Lukang Tianhou Temple was analyzed: 121 people chose to visit the temple, accounting for $46.5 \%$, chatting with 2 people accounting for $0.8 \%$, walking 34 people accounting for 13.1 people, participating in activities 12 people accounted for $4.6 \%$, 3 volunteers accounted for $1.2 \%$, and recreational staff accounted for $33.8 \%$. (2) Analysis of the frequency of interviewees visiting Lukang Tianhou Temple: 5 people per day accounted for $1.9 \%, 4$ people accounted for $1.5 \%$ in 1 week, 2 people accounted for $0.8 \%$ in 2 weeks, and 12 people accounted for 4.6 in 1 month \%, 1.5\% were 4 persons in 2 months, $2.7 \%$ were 7 persons in 3 months, $14.6 \%$ were 38 persons in half a year, $11.9 \%$ were 31 persons in a year, and 157 persons who visited irregularly accounted for $60.4 \%$. (3) Analysis of the transportation vehicles that respondents usually use to go to Lukang Tianhou Temple: 3 people choose to hike $1.2 \%, 13$ people use bicycles, 5\%, 85 people use motorcycles, $32.7 \%$, and 154 people use cars for their own use. $59.2 \%, 0.8 \%$ with 2 taxis and $1.2 \%$ with 3 bus. (4) Respondents usually go to Lukang Tianhou Temple to follow the companions: 143 family members account for $55 \%, 85$ friends account for $32.7 \%, 14$ colleagues account for $5.4 \%$, and 3 classmates account for 1.2 . Fifteen people went alone, accounting for 5.8\%. (5) Respondents accept tourism information sources as: 123 family members and friends accounted for $47.3 \%, 27$ 
colleagues accounted for $10.4 \%, 9$ classmates accounted for $3.5 \%, 32$ online accounts accounted for $12.3 \%$, newspapers and magazines accounted for 11 People accounted for $4.2 \%$, and communication platforms (such as FB, Line) had 6 people accounted for $2.3 \%$. (6) The average expenditure of the interviewees during the visit was (NTD): 112 people accounted for $43.1 \%$ under 1,000 dollars, 77 people accounted for $29.6 \%$ of 1001 2000 dollars, and 43 people accounted for $16.5 \%$ of 2001-3000 dollars. Between 4000 and 5000 dollars, 22 persons accounted for $8.5 \%$, and more than 5000 dollars, 6 persons accounted for $2.3 \%$.

\subsection{Regression empirical results and analysis}

\subsubsection{Measurement model analysis}

In this study, the Partial Least Squares (PLS) path model is a non-parametric method, and the requirements for the number of samples are looser, and the number of samples is not a normal distribution; as well as small sample research investigations. According to the judgment criteria of Hair, Ringle, \& Sarstedt, (2011) [41], the reliability of individual variables, composite reliability (CR) and Cronbach' $\alpha$ of potential variables, and average extraction (Average Extracted Variance, AVE) is the main method for judging reliability and convergence validity, and uses Bootstraping to solve the problem of small samples and non-multivariate normality of data to obtain the stability of estimates of various variables (Chin, 2010) [42]. This study uses Smart PLS 3.0 tools to perform PLS analysis. The relevant verification standards are described as follows: (1) The reliability of individual measurement variables mainly considers the degree to which each measurement variable can be explained by the potential variables. It is recommended that the factor load value (Outer loadings) should be above 0.7 (Barclay, Higgins, \& Thompson, 1995) [43] After analysis, most of the factor loading values of factors such as temple tourism involvement, place identity, satisfaction, and willingness to revisit are greater than 0.7. Because of the low load value of factors place dependent, the dimension of place attachment was replaced by place identity, and follow-up statistical analysis was performed on this dimension, as shown in Table 2.1, 2.2, 2.3.

Table 2. Loading of factors involved in temple activities

\begin{tabular}{|l|l|}
\hline $\begin{array}{l}\text { Table 2.1 Loading of factors involved in temple } \\
\text { activities }\end{array}$ \\
\hline Item & Out loading \\
\hline Attractive Q1-Q6 & 0.717 \\
\hline Q1. I like to visit temples & 0.724 \\
\hline $\begin{array}{l}\text { Q2. Participating in temple activities is } \\
\text { very important to me }\end{array}$ & 0.688 \\
\hline Q3. I go to the temple to relieve my stress & 0.724 \\
\hline $\begin{array}{l}\text { Q4. Temple activity is one of my most } \\
\text { satisfied activities }\end{array}$ & $\begin{array}{l}-0.294 \\
\text { Q5. I am not interested in temple } \\
\text { activities }\end{array}$ \\
\hline Q6. I feel very happy to go to the temple & 0.798 \\
\hline
\end{tabular}

\begin{tabular}{|l|l|}
\hline \multicolumn{2}{|l|}{ Centrality to lifestyle Q7-Q10 } \\
\hline $\begin{array}{l}\text { Q7. I will discuss temple activities with } \\
\text { my friends }\end{array}$ & 0.762 \\
\hline $\begin{array}{l}\text { Q8. My life and temple activities is very } \\
\text { relevant }\end{array}$ & 0.770 \\
\hline $\begin{array}{l}\text { Q9. I would like to invite friends and } \\
\text { family to participate in temple activities }\end{array}$ & 0.773 \\
\hline $\begin{array}{l}\text { Q10. Temple activities are a part of my } \\
\text { life }\end{array}$ & 0.798 \\
\hline Self-expression Q11-Q14 & 0.822 \\
\hline $\begin{array}{l}\text { Q11. There will be more topics to talk } \\
\text { about when I go to temples with my } \\
\text { family and friends }\end{array}$ & 0.810 \\
\hline $\begin{array}{l}\text { Q12. I can show my truest self when } \\
\text { participating in temple activities }\end{array}$ & 0.776 \\
\hline $\begin{array}{l}\text { Q13. When I meet people asking about } \\
\text { temple activities, I can tell them many } \\
\text { stories about temples. }\end{array}$ & 0.768 \\
\hline $\begin{array}{l}\text { Q14 Others can understand who I am by } \\
\text { seeing my activities in the temple. }\end{array}$ \\
\hline
\end{tabular}

\begin{tabular}{|c|c|}
\hline Item & $\begin{array}{l}\text { Out } \\
\text { loading }\end{array}$ \\
\hline \multicolumn{2}{|l|}{ Place dependenceQ15-Q20 } \\
\hline $\begin{array}{l}\text { Q15. I feel free and comfortable when } \\
\text { visiting Lukang Tianhou Temple }\end{array}$ & $\begin{array}{l}-0.239 \\
(\mathrm{P}>.05)\end{array}$ \\
\hline $\begin{array}{l}\text { Q16. I think Lukang Tianhou Temple is } \\
\text { the best place to participate in temple } \\
\text { activities }\end{array}$ & $\begin{array}{l}-0.239 \\
(\mathrm{P}>.05)\end{array}$ \\
\hline $\begin{array}{l}\text { Q17. Lukang Tianhou Temple is my } \\
\text { most frequent temple since I was young }\end{array}$ & $\begin{array}{l}-0.239 \\
(\mathrm{P}>.05)\end{array}$ \\
\hline $\begin{array}{l}\text { Q18. Lukang Tianhou Temple's facilities } \\
\text { surpass other temples }\end{array}$ & $\begin{array}{l}-0.239 \\
(\mathrm{P}>.05)\end{array}$ \\
\hline $\begin{array}{l}\text { Q19. My spiritual satisfaction in Thean } \\
\text { Hou Temple in Lukang is far more than } \\
\text { other temples }\end{array}$ & $\begin{array}{l}-0.239 \\
(\mathrm{P}>.05)\end{array}$ \\
\hline $\begin{array}{l}\text { Q20. For me, there is no other temple } \\
\text { that can replace Lukang Tianhou Temple }\end{array}$ & $\begin{array}{l}-0.239 \\
(\mathrm{P}>.05)\end{array}$ \\
\hline \multicolumn{2}{|l|}{ Place identity Q21-Q28 } \\
\hline $\begin{array}{l}\text { Q21. I have deep feelings for Lukang } \\
\text { Tianhou Temple }\end{array}$ & 0.850 \\
\hline $\begin{array}{l}\text { Q22. I often visit Lukang Tianhou } \\
\text { Temple with my family or friends }\end{array}$ & 0.831 \\
\hline $\begin{array}{l}\text { Q23. I strongly agree with Lukang } \\
\text { Tianhou Temple }\end{array}$ & 0.823 \\
\hline $\begin{array}{l}\text { Q24. I have a deep understanding of } \\
\text { Lukang Tianhou Temple }\end{array}$ & 0.804 \\
\hline $\begin{array}{l}\text { Q25. Lukang Tianhou Temple is of great } \\
\text { significance to me }\end{array}$ & 0.760 \\
\hline $\begin{array}{l}\text { Q26. Lukang Tianhou Temple is very } \\
\text { strange to me }\end{array}$ & $\begin{array}{l}-0.230 \\
(\mathrm{P}>.05)\end{array}$ \\
\hline $\begin{array}{l}\text { Q27. I am more satisfied with Lukang } \\
\text { Tianhou Temple than other temples }\end{array}$ & 0.829 \\
\hline $\begin{array}{l}\text { Q28. I have many memories of visiting } \\
\text { and participating in activities at Tianhou } \\
\text { Temple in Lukang }\end{array}$ & 0.812 \\
\hline
\end{tabular}

\begin{tabular}{|l|l|}
\hline \multicolumn{2}{|l|}{ Table 2.3 Loading of satisfaction factors } \\
\hline item & Out loading \\
\hline Psychological needs Q29-Q32 \\
\hline
\end{tabular}




\begin{tabular}{|c|c|}
\hline $\begin{array}{l}\text { Q29. Are you satisfied with visiting } \\
\text { the temple to relieve stress and } \\
\text { anxiety? }\end{array}$ & 0.617 \\
\hline $\begin{array}{l}\text { Q30. Are you satisfied with the peace } \\
\text { of mind provided by the temple? }\end{array}$ & 0.653 \\
\hline $\begin{array}{l}\text { Q31. Are you satisfied with the } \\
\text { provision of tourist advisory services? }\end{array}$ & 0.574 \\
\hline $\begin{array}{l}\text { Q32. Are you satisfied with the } \\
\text { service attitude of the temple staff? }\end{array}$ & 0.622 \\
\hline \multicolumn{2}{|l|}{ Environmental needs Q33-Q37 } \\
\hline $\begin{array}{l}\text { Q33. Are you satisfied with the } \\
\text { cleanliness of the temple environment? }\end{array}$ & 0.784 \\
\hline $\begin{array}{l}\text { Q34. Are you satisfied with the } \\
\text { convenience of parking provided by } \\
\text { the temple? }\end{array}$ & 0.615 \\
\hline $\begin{array}{l}\text { Q35. Are you satisfied with the route } \\
\text { planning for the direction of worship } \\
\text { in the temple? }\end{array}$ & 0.738 \\
\hline $\begin{array}{l}\text { Q36. Are you satisfied with the signs } \\
\text { and road signs of Tianhou Temple at } \\
\text { arrival Gate? }\end{array}$ & 0.743 \\
\hline $\begin{array}{l}\text { Q37. Are you satisfied with Lianwai } \\
\text { Transportation? }\end{array}$ & 0.688 \\
\hline $\begin{array}{l}\text { Q38. Are you satisfied with the dim } \\
\text { sum provided by the temple? }\end{array}$ & 0.772 \\
\hline $\begin{array}{l}\text { Q39. Are you satisfied with the } \\
\text { cleanliness of the temple's toilets? }\end{array}$ & 0.573 \\
\hline \multicolumn{2}{|l|}{$\begin{array}{l}\text { Aspects of cultural preservation of ancient } \\
\text { achievements Q38-Q43 }\end{array}$} \\
\hline $\begin{array}{l}\text { Q40. Are you satisfied with the } \\
\text { carving and design of temple walls or } \\
\text { beams? }\end{array}$ & 0.724 \\
\hline $\begin{array}{l}\text { Q41. Are you satisfied with the art } \\
\text { display of sculptures and cultural } \\
\text { relics in Tianhou Temple? }\end{array}$ & 0.748 \\
\hline $\begin{array}{l}\text { Q42. Are you satisfied with the price } \\
\text { of the souvenirs provided by the } \\
\text { temple? }\end{array}$ & 0.751 \\
\hline $\begin{array}{l}\text { Q43. Are you satisfied with the rich } \\
\text { cultural heritage of Tianhou Temple? }\end{array}$ & 0.555 \\
\hline $\begin{array}{l}\text { Q44. You can satisfy your religious } \\
\text { curiosity about traveling to temples? }\end{array}$ & 0.606 \\
\hline $\begin{array}{l}\text { Q45. Are you satisfied with the } \\
\text { explanation signs of the temple and the } \\
\text { signs for indoor walking lines? }\end{array}$ & 0.784 \\
\hline
\end{tabular}

\begin{tabular}{|l|l|}
\hline \multicolumn{2}{|c|}{ Table 2.4 Loading of factors of willingness to revisit } \\
\hline item & Out loading \\
\hline $\begin{array}{l}\text { Q46. Would you like to come back to } \\
\text { Lukang Tianhou Temple again? }\end{array}$ & 0.973 \\
\hline $\begin{array}{c}\text { Q47. Would you like to recommend } \\
\text { others to Lukang Tianhou Temple? }\end{array}$ & 0.970 \\
\hline
\end{tabular}

(2) Composite reliatbility (CR) refers to the consistency of the internal variables of the facet. When the CR value of the potential variable and Cronbach' $\alpha$ is higher, the potential variable can be tested. It is recommended that Cronbach' $\alpha$ must be greater than 0.7
$(0.60 \sim 0.70$ in exploratory research) is enough to represent that the potential variables have good internal consistency (as shown in Table 1). After analysis, the reliability and validity of the combination of factors such as temple tourism involvement, place identity, satisfaction, willingness to revisit, etc. are mostly greater than 0.7 as shown in Table 3.

Table 3. Combination validity

\begin{tabular}{|c|c|}
\hline factor & CR \\
\hline $\begin{array}{c}\text { temple tourism } \\
\text { involvement }\end{array}$ & 0.936 \\
\hline place identity & 0.758 \\
\hline satisfaction & 0.937 \\
\hline Willingness to revisit & 0.971 \\
\hline
\end{tabular}

(3) Average variance extracted (AVE) is a value that represents how many potential variables can be tested by a variable. It can not only judge the reliability, but also represent the discriminant validity. According to the recommendations of Fornell and Larcker (1981) [44], the AVE value must be greater than 0.5 in order to represent the convergence effect of the observation variable. In addition, check the collinearity problem of each group of forecast variables. The prediction construct tolerance (Variance inflation factor, VIF) is less than 0.20 , which means that there is a collinearity problem. After verification, its constructs are all greater than 0.20 , so there is no collinearity. After analysis, the average variation extraction amount AVE of factors such as temple tourism involvement, place identity, satisfaction, willingness to revisit, etc. is mostly greater than 0.5 , as shown in Table 4.

Table 4. Average variation extraction amount

\begin{tabular}{|c|c|}
\hline factor & AVE \\
\hline temple tourism involvement & 0.549 \\
\hline place identity & 0.507 \\
\hline satisfaction & 0.512 \\
\hline Willingness to revisit & 0.945 \\
\hline
\end{tabular}

\subsubsection{PLS module path results}

After the above analysis of reliability and validity, SmartPIS3.0 software is used to analyze and verify the causal relationship among the potential variables of the structural model. In this study, 300 times of bootstrapping parameter settings were used to verify the program to obtain the stability of each variable estimate (Chin, 2010) [42]. Next, the analysis effect value $\mathrm{f}^{2}$ can be used to evaluate the influence of extrinsic variables on the internal dependent variables of the explanatory variables. The general principles $0.02,015$, and 0.35 
represent the small, medium, and large effects of extrinsic variables on internal latent variables. The analysis shows that the temple tourism involvement has an impact on place identity, temple tourism involvement has an impact on satisfaction, and satisfaction has an impact on the willingness to revisit, as shown in Table 5.

Table 5. total effect value table

\begin{tabular}{|l|l|}
\hline \multicolumn{1}{|c|}{ total effect } & $\mathrm{f}$ - square \\
\hline $\begin{array}{l}\text { temple tourism involvement-> place } \\
\text { identity }\end{array}$ & $0.499^{*}$ \\
\hline $\begin{array}{l}\text { temple tourism involvement- } \\
>\text { satisfaction }\end{array}$ & $0.559^{*}$ \\
\hline Satisfaction->Willingness to revisit & $0.685^{*}$ \\
\hline
\end{tabular}

$* \mathrm{P}<0.05,{ }^{* *} \mathrm{p}<0.01,{ }^{* * *} \mathrm{p}<0.001$

We use R-Square to judge path significance test and research model interpretation ability. The coefficient of determination of $\mathrm{R}^{2}$ represents the size of the potential internal variables in the structural formula to be explained. The general principles of $0.75,0.50$, and 0.25 represent that the $\mathrm{R}^{2}$ value can be roughly classified as significant large, medium and small effects. After the analysis of this study, the analysis showed that temple activities involved in place identity, temple activities involved in satisfaction, and satisfaction had an impact on the willingness to revisit. The $\mathrm{R}^{2}$ values are all significant, as shown in Table 6.

Table 6. $\mathrm{R}^{2}$ coefficient of value

\begin{tabular}{|l|c|}
\hline \multicolumn{1}{|c|}{ total effect } & $\mathrm{R}^{2}$ \\
\hline $\begin{array}{l}\text { temple tourism involvement-> place } \\
\text { identity }\end{array}$ & $0.499^{*}$ \\
\hline $\begin{array}{l}\text { temple tourism involvement- } \\
\text { >satisfaction }\end{array}$ & $0.507^{*}$ \\
\hline Satisfaction->Willingness to revisit & $0.570^{*}$ \\
\hline
\end{tabular}

$* \mathrm{P}<0.05,{ }^{* *} \mathrm{p}<0.01,{ }^{* * *} \mathrm{p}<0.001$

The R-squared value is the percentage of variance explained by exogenous variables versus endogenous variables. It represents the predictive ability of the research model. Its value is between 0 and 1 . The larger the value, the better the explanatory ability of the model. The results of the overall model relationship path verification presented by the four research hypotheses proposed by this research respectively show that the involvement of temple activities has a positive impact on place identity. At the same time, involvement in temple activities has a positive effect on satisfaction. Place identity has a positive effect on satisfaction. Satisfaction has a positive effect on willingness to revisit. The results of the research hypothesis test results of this research are shown in Table 7 and attached Figure 1.
Table 7. Empirical results of research hypothesis verification of structural model

\begin{tabular}{|c|c|c|c|}
\hline Item & Hypothesis & $\begin{array}{c}\text { Path } \\
\text { Coefficients }\end{array}$ & Results \\
\hline H1 & $\begin{array}{c}\text { The involvement of } \\
\text { temple activities has } \\
\text { a positive impact on } \\
\text { place identity }\end{array}$ & $0.499^{*}$ & support \\
\hline H2 & $\begin{array}{c}\text { The involvement of } \\
\text { temple activities has } \\
\text { a positive impact on } \\
\text { satisfaction }\end{array}$ & $0.402^{*}$ & support \\
\hline H3 & $\begin{array}{c}\text { Place identity has a } \\
\text { positive impact on } \\
\text { satisfaction }\end{array}$ & $0.401^{*}$ & support \\
\hline H4 & $\begin{array}{c}\text { Satisfaction has a } \\
\text { positive effect on } \\
\text { willingness to revisit }\end{array}$ & $0.685^{*}$ & support \\
\hline
\end{tabular}

${ }^{*} \mathrm{P}<0.05,{ }^{* *} \mathrm{p}<0.01,{ }^{* * *} \mathrm{p}<0.001$

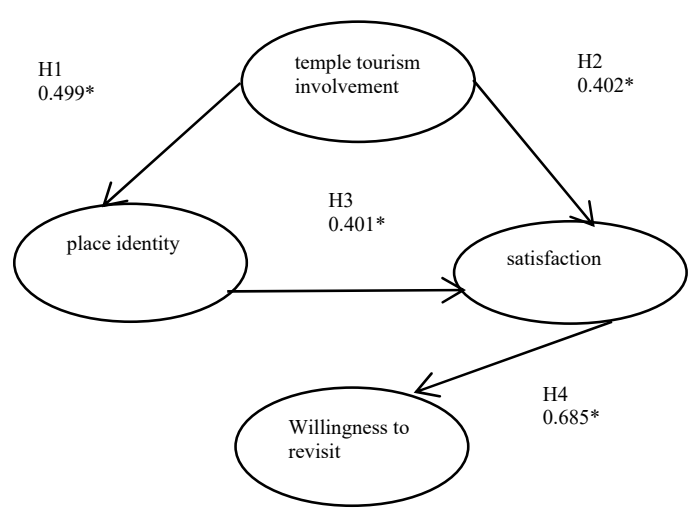

Fig. 1. Analysis model diagram.

\section{Conclusion}

\subsection{Tourists' socioeconomic background and characteristics}

From this survey, it was found that the age groups of those participating in temple cultural activities were distributed in each age group. The education level is mostly college level or above. Unmarried people account for the majority of the population. This survey shows that participating in temple cultural activities is universal and acceptable to the average middle class. In addition, it is found from the analysis that the interviewees' participation in temple activities is mainly for worship and recreation. And the frequency of participation is the most frequent visits from time to time. And the nearby temple is the first choice. The religious beliefs of the interviewees are Buddhism and Taoism accounting for the largest proportion.

\subsection{Analysis of factors affecting temple activities}

After questionnaire survey and statistical analysis, the results of the overall model relationship path verification 
presented by the four research hypotheses proposed by this research respectively show that the involvement of temple activities has a positive impact on place identity. The involvement of temple activities has a positive effect on satisfaction. Place identity has a positive effect on satisfaction. Satisfaction has a positive effect on willingness to revisit. All meet the original assumptions. It shows that the involvement of temple activities is a very common thing for Taiwanese in daily life, and the participation in temple activities is integrated with the usual leisure and recreation. Participants will also choose to go to the temple to relieve their personal work pressure, make friends and talk, and family gatherings. Temple activities are already one of the indispensable places for life, leisure and recreation, and also a place to calm people's hearts.

\section{References}

1. C.L.Chang.Journey of Saint Boat: A psychic's selfnarrative of meaning and the practice of life. Nanhun University master thesis, Taiwan(2015)

2. E.T.Lee.Managing traditional temples: a case study of representative temples in CHIA-YI. Nanhun University master thesis, Taiwan(2006)

3. G. Rinschede. Forms of religious tourism. Annals of Tourism Research, 19(1), 51-67(1992)

4. M. L.Nolan, S.Nolan. Religious sites as tourism attractions in Europe. Annals of Tourism Research, 19(1), 68-78 (1992)

5. B.Vukonic. Tourism and religion (S. Matesic', Trans.) British: University of Zagreb, Original work pubished, 21, 68. (1992)

6. C.H.Hu.The leisure cognition, involvement and experiences of college students: effects of personality traits.Kaohsiung Medical University Master Thesis, Taiwan(1999)

7. W.C.Yang. A study on relationships among leisure motivation, leisure involvement and leisure benefits of bikers.Journal of Leisure and Tourism Industry Research.4(2), 84-95(2009)

8. S .H.Wang.The impacts of civil servants' leisure involvement on leisure benefits, happiness and quality of work life: an empirical study of Taitung County. Taitung University master thesis, Taiwan (2016)

9. Are religious people happier, healthier? Our new global study explores this question(2019) https://www.pewresearch.org

10. H.E.Krugman. Impact of television advertising learning without involvement. Public Opinion Quarterly, 29, 349-356(1965)

11. B.Vukonic. Medjugorje's religious and tourism connection, Annals of Tourism Research, 19(1), 7991(1992)

12. G.Rinschede. Forms of religious tourism. Annals of Tourism Research, 19(1), 51-67(1992)
13. H.C.Yu.The study of religious tourists travel motivation and satisfaction:a case study of Taitian tample of Nan Kun Shen, Tannan, Taiwan.Chinese Culture University master thesis, Taiwan(2000)

14. R.Barber.Pilgrimages, Lodon: The Boydell Press. (1993)

15. Y.Y.Yan. An Analysis of Religious Tourism. Journal of Xiamen University, 143(3), 69-73(2000)

16. G. Laurent, J. N. Kapferer. Measuring consumer involvement profiles, Journal of Marketing Research, 22, 41-53 (1985)

17. N. McIntyre, J.J. Pigram. Recreational specialization reexamined: The case of vehiclebased campers. Leisure science, 14,3-15 (1992)

18. G. Kyle, G.Chick.The social natural of leisure involvement. Journal of Leisure Research, 34(4), 426-444(2002)

19. Y. F.Tuan.Space and place: the perspective of experience. minneapolis: University of Minnesota Press(1977)

20. S. A. Shumaker, R. B.Taylor.Toward a clarification of people-place relationships: A model of attachment to place. In N. R. Feimer and E. S. Geller, Eds., Environmental Psychology: Directions and Perspectives. New York, U.S.A.: Praeger, 219251(1983)

21. M. D. S.Ainsworth,S. Bell.Attachment,exploration, and separation: illustrated by the behavior of one-year-old in a strange situation.Child Development,41(1),4967(1970)

22. L.Scannell, R.Gifford.The relations between natural and civic place attachment and proenvironmental behavior. Journal of Environmental Psychology, 30 (3), 289-297.(2010)

23. K. S.Bricker,D. L Kerstetter.Level of specialization and place attachment:an exploratory study of whitewater Sciences.4(22),233-257(2010)

24. R.S.Feldman.Social psycholog. 2th, New Jersey: Prentice-Hall.(1998)

25. G.Shannon,J.R.Edward.The effect of goal orientation \& place dependence on select goal interferences among winter backcountry users. Leisure Science,17,171-183(1995)

26. R. L.Moore,A.R.Graefe.Attachments to recreation settings: the case of rail-trail users, Leisure Sciences, 16,17-31(1994)

27. H.M.Proshansky,A.K.Fabian,R.Kaminoff.Placeidentity:physical world socialization of the self, Journal of Environmental Psychology, 3,57-83(1983)

28. D.A.Baker,J.L.Crompton.Quality,Satisfaction and Behavioural Intentions. Annals of Tourism Research, 27(3),785-804(2000)

29. J.G.Beard,M.G.Ragheb.Measuring leisure satisfaction.Journal of Leisure Research,12(1),2033(1980) 
30. B.L.McFarlane, P. C.,Boxall, \& D. O. Watson.Past experience and behavioral choice among wilderness users. Journal of Leisure Research, 30, 195213(1998).

31. R.Schreyer,D.W.Lime,D.R.Williams.Characterizing the influence of past experience on recreation behavior, Journal of Leisure Research, 16,3450.science, 12,179-195(1984).

32. Y.J.Peng.A Study on Relationships between Recreation Involvement and Place Attachmant of Recreation Bikers.Ming Chuan University master thesis, Taiwan(2004)

33. C.M.Tung. The study of religious activity involvement and place attachment:a case of Dong Lung Temple in Dong Gang.Asia University master thesis, Taiwan(2011)

34. Y.H,Chu.The multiple views on the benefits of religious tourism.Taipei City University of Science \& Technology master thesis, Taiwan(2014)

35. C.H.Liu.The relationship among recreation involvement, place attachment and satisfaction of bikers: a case study of Love River bike path.Kaohsiung University of Science and Technology master thesis, Taiwan(2008)

36. G.Kyle,A.Graefe,R.Manning,J.Bacon.An examination of the relationship between leisure activity involvement and place attachment among hikers along the appalachain trail. Journal of Leisure Research, 35, 249-273(2003)

37. G.Kyle,K.Bricker,A.Graefe,T.Wickham.An examination of the relationships with activities and settings. Leisure Science, 26, 123-142(2004)

38. Ting, Chi-Hsiang., C.L.Chang .Factors Affecting Consumer's Experience within Tea house.Journal of Physics:conference Series.1168.IOP publishing(2016)

39. Y.S.Lai.A study of the tourism motivation, satisfaction and revisit intention of religious sightseeing Tourism:a case study of Luermen Tin Hou Temple in Tainan.TOKO University master thesis, Taiwan(2014)

40. C.C.Shen,C.Y.Hsieh.A study on the relationship among attraction, tourist satisfaction loyalty of religious tourism: a case of Fo Guang Shan in Kaohsiung.Tourism Management Research.3(1),7995. Taiwam(2003).

41. J. F.Hair,C. Ringle,M. Sarstedt. PLS-SEM: Indeed a silver bullet. Journal of Marketing Theory and Practice,19,139-151(2011)

42. W. W.Chin. Bootstrap cross-validation indices for PLS path model assessment, in Vinzi, V. E. et al. (eds). Handbook of partial least squares: concepts, methods and applications. Heidelberg: Springer, 8397(2010)

43.D.Barclay,C. Higgins, R.Thompson. The Partial Least Squares (PLS) Approach to Causal Modeling: Personal Computer Adoption and Use as an Illustration. Technology Studies,2(2), 285-309(1995)
44. C.Fornell, D. FLarcker. Evaluating Structural Equation Models with Unobservable Variables and Measurement Error. Journal of Marketing Research, 18(1), 39-50 (1981) 